UDC 316.61

LBC 60.54

\title{
PROSPECTS OF IMPLEMENTING THE TECHNOLOGY OF INCLUDING ELDERLY PEOPLE IN SOCIALIZING GRADUATES OF ORPHANAGES
}

\author{
Elena A. Kuzmina \\ Volgograd State University, Volgograd, Russian Federation
}

\begin{abstract}
The increase of life expectancy in the Russian Federation contributes to the expansion of the field of theoretical and empirical studies of the problems of elderly people. The interest is stipulated by the fact that the processes of socialization and re-socialization of the actors of this age group were at a change of ideology, economic relations, values, which can explain the behavioral characteristics of elderly people (a tendency to save, caution, prudence, anxiety, fear for the future), which often cause ridicule and misunderstanding on the part of other age groups. Consequently, people of the "third age" find themselves in social isolation, which exacerbates their economic, social, psychological, domestic and other problems. The article proposes to consider the problems of people of the "third age" and the technology of interaction between the elderly and young people. The generation of people of the "third age" has enormous experience and unique knowledge, which may not be used enough in the social practice and institutional system of the Russian Federation.

The author substantiates the need to introduce an innovative model that ensures the successful secondary socialization of elderly people through their participation in the socialization of graduates of orphanages. Despite the existing measures of social support from the state, the majority of elderly people feel social loneliness. Low level of social activity, incompetence in solving economic, political, housing issues can cause additional crises of social and personal development.

The paper pays special attention to the study of the experience of cohabitation of students and third-aged citizens at the territory of social rehabilitation centers in America. A comparative analysis of the state of stationary social service institutions in Russia, Europe and America is given. Testing of the technology of cohabitation of third-aged persons and students from among the former inmates of children's homes on the Russian soil is possible only under the condition of complete transformation of stationary institutions of social service of elderly citizens. Prospects of introduction of this technology in gerontological centers of the Russian Federation are defined. Integrated institutions of cohabitation will solve a number of problems: to overcome the social isolation of the elderly, to strengthen control over the activities of institutions, to optimize the socialization of children in orphanages, to reduce the cost of social support for children left without parental care, until the moment of providing them with housing.
\end{abstract}

Key words: gerontological center, orphans, intergenerational interaction, old age, resocialization, socialization, socially oriented activities, the "third age".

УДК 316.61

ББК 60.54

\section{ПЕРСПЕКТИВЫ ВНЕДРЕНИЯ ТЕХНОЛОГИИ ВКЛЮЧЕНИЯ ПОЖИЛЫХ ЛЮДЕЙ В СОЦИАЛИЗАЦИЮ ВЫПУСКНИКОВ ДЕТСКИХ ДОМОВ}

\section{Елена Алексеевна Кузьмина}

Волгоградский государственный университет, г. Волгоград, Российская Федерация

Аннотация. Рост продолжительности жизни на территории Российской Федерации способствует расширению поля теоретических и эмпирических исследований проблем пожилых людей. Интерес обусловлен тем, что процессы социализации и ресоциализации акторов данной возрастной группы шли при смене 
идеологии, экономических отношений, ценностей, что может объяснить поведенческие особенности пожилых людей (склонность к накоплениям, осторожность, рассудительность, тревожность, страх за будущее), которые часто вызывают насмешки и непонимание со стороны других возрастных групп. Вследствие этого люди «третьего возраста» оказываются в социальной изоляции, что усугубляет их экономические, социальные, психологические, бытовые и иные проблемы. В статье предлагается рассмотреть проблемы людей «третьего возраста» и технологии взаимодействия пожилых и молодых людей. Поколение людей «третьего возраста» обладает колоссальным опытом и уникальными знаниями, что может недостаточно используется в социальной практике и институциональной системе РФ.

Автор обосновывает необходимость внедрения инновационной модели, обеспечивающей успешную вторичную социализацию людей пожилого возраста посредством их участия в социализации выпускников детских домов. Несмотря на существующие меры социальной поддержки со стороны государства, в большинстве своем пожилые люди чувствуют социальное одиночество. Низкий уровень социальной активности, некомпетентность в решении экономических, политических, жилищно-бытовых вопросов могут вызвать дополнительные кризисы социального и личностного развития.

В работе уделено особое внимание изучению имеющегося в Америке опыта совместного проживания студентов и граждан «третьего возраста» на территории социально-реабилитационных центров. Дан сравнительный анализ состояния стационарных учреждений социального обслуживания России, стран Европы и Америки. Апробация технологии совместного проживания лиц «третьего возраста» и студентов из числа бывших воспитанников детских домов на российской почве возможна лишь при условии полной трансформации стационарных учреждений социального обслуживания граждан пожилого возраста. Определены перспективы внедрения данной технологии в геронтологических центрах Российской Федерации. Интегрированные учреждения совместного проживания позволят решить ряд задач: преодолеть социальную изоляцию пожилых людей, усилить контроль за деятельностью учреждений, оптимизировать социализацию воспитанников детских домов, сократить расходы на социальную поддержку детей, оставшихся без попечения родителей, до момента предоставления им жилья.

Ключевые слова: геронтологический центр, дети-сироты, межпоколенческое взаимодействие, пожилой возраст, ресоциализация, социализация, социально ориентированная деятельность, «третий возраст».

Введение. Современное российское общество на треть состоит из людей «третьего возраста», который соответствует периоду активной жизни и начинается с момента выхода человека на пенсию. Очевидна актуальность изучения социальных проблем пожилых людей и перспектив их ресоциализации («возврат в общество посредством осуществления социально ориентированной деятельности, через которую пожилой человек обретает возможность трансляции жизненного опыта, а также возможность самореализации» [6, c. 49]). При регулярном взаимодействии с другими поколениями пожилые люди обретают новые социальные роли, что подчеркивает их социальную значимость. Поколение людей «третьего возраста» можно включить в технологии усовершенствования социальной политики российского государства, используя их опыт и уникальные знания для адаптации детей-сирот к выходу из детского дома.

Следует отметить, что социализация детей-сирот будет успешной, если в социуме сформировано позитивное отношение к пожилым людям. Проявление предвзятого отношения к представителям старшего поколения, так называемый «эйджизм» (термин был введен директором национального института старения США Р.Н. Батлером), является показателем низкого уровня образованности и отсутствия социально ориентированного воспитания. Вследствие завершения периода активной трудовой деятельности, наступления физиологических и иных возрастных изменений ограничивается количество и качество взаимодействий пожилого человека с обществом, что вызывает ощущение «утраты социальной полноты жизни» [19, с. 105]. Решение таких социальных проблем, как устранение дискриминации по возрастному признаку и сокращение социальной дистанции между поколениями, должно стать одним из приоритетных направлений социальной политики российского государства.

В связи с этим основная гипотеза настоящего исследования заключается в предположении о том, что вследствие регулярного социального взаимодействия с выпускниками детских домов пожилые люди смогут почувствовать свою социальную значимость, обрести новые социальные роли и, как следствие, 
успешно пройти путь ресоциализации, минуя социальную изоляцию. К сожалению, проблема социального отчуждения личности характерна не только для лиц пожилого возраста [21, с. 191]. Ввиду отсутствия положительного опыта межпоколенческого взаимодействия зачастую с ним сталкиваются и воспитанники детских домов. Изучением проблем социального отчуждения личности детей и подростков в РФ занимались Я.И. Гилинский [5], Е.В. Змановская [9], Ю.А. Клейберг [12], В.Н. Кудрявцев [14], А.А. Сукало [20] и др. Основная проблема их исследований - как преодолеть социальную изоляцию и отстраненность от всякого рода взаимодействий, гипотеза - посредством регулярного дружеского общения, наставничества, поддержки и внимания со стороны взрослых людей. Всего этого можно достичь при условии совместного проживания выпускников детских домов с людьми пожилого возраста в специально оснащенных социально-реабилитационных центрах. Вместе они образуют группу взаимопомощи, способную искоренить проблемы социального отчуждения и социальной изоляции.

Ресоциализация через технологии взаимодействия пожилых, подростков, молодежи. По мнению М.В. Ермолаевой, «возможный путь развития личности в старости - это ресоциализация, то есть возврат в общество посредством осуществления социально значимой деятельности, благодаря которой происходит поддержание и развитие регулярных взаимодействий с обществом» [8, c. 102]. Следует обратить внимание на отсутствие в российском государстве отлаженного механизма социального взаимодействия пожилых людей с представителями последующих поколений. В силу профессионального рода деятельности некоторые из них являются учителями, творческими и духовными наставниками на протяжении всей своей социально-активной жизни, вплоть до периода ограниченной дееспособности. Однако это узконаправленные сферы искусства, науки и культуры. Знания, а самое главное жизненный опыт большинства остаются, к сожалению, невостребованными. Таким образом, возникает необходимость в создании уникальной технологии взаимодействия представителей разных поколений.
В качестве рекомендаций предлагаем рассмотреть возможную модель социального взаимодействия пожилых людей с выпускниками детских домов, поскольку имеющиеся уникальные знания, профессиональные умения и навыки наиболее востребованы детьми, воспитывающимися в условиях социальных учреждений. Процесс аккумуляции знаний, передача жизненного опыта являются неотъемлемой частью регулярного семейного общения. У детей, лишенных родительского попечения, отсутствует опыт взаимодействия с представителями старших поколений. Вследствие недостаточного количества внимания и заботы со стороны взрослых возможно возникновение «депривации» (термин был введен английским психологом Джоном Боулби), что обозначает задержку эмоционального, физического, психического и интеллектуального развития, ввиду отсутствия у ребенка социальных контактов [3, с. 34]. Следует отметить, что к моменту выпуска из детского дома дети, оставшиеся без попечения родителей, не обладают знаниями и умениями для самостоятельной организации жизни за пределами учреждения. Процесс социального взаимодействия с представителями старших поколений может быть полезен для успешной социализации и безболезненной адаптации детей-сирот к условиям взрослой жизни, если будут созданы и внедрены новые социальные технологии.

Проанализируем существующую в Америке модель совместного проживания лиц пожилого возраста со студентами. В обмен на дружеское общение и посильную помощь в оказании бытовых и иных видов социальных услуг им могут быть сданы в аренду комнаты домов престарелых по приемлемым ценам. Данная модель межличностного взаимодействия направлена прежде всего на экономическую поддержку студентов со стороны государства и частично на ресоциализацию людей пожилого возраста. В основном это касается людей старческого возраста, имеющих ограниченные возможности здоровья. Проживание в домах для пожилых людей в странах Европы и Америки - это прежде всего определенный уровень материального благосостояния, статуса в обществе. Произведенные в течение всей жизни накопления позволяют 
иностранцам «третьего возраста» жить полноценной жизнью, не испытывая проблем с депривацией и социализацией. Для многих из них начинается новый жизненный этап: создаются семьи, осваиваются новые увлечения, совершаются путешествия, происходят новые знакомства не только на территории учреждений, но и за их пределами.

Препятствия для совместного проживания пожилых и молодых. Следует отметить, что апробация технологии совместного проживания лиц «третьего возраста» и студентов из числа бывших воспитанников детских домов на российской почве возможна лишь при условии полной трансформации стационарных учреждений социального обслуживания граждан пожилого возраста. Состояние, в котором они находятся в настоящий момент времени, является крайне непригодным для проживания студентов. Социальная реабилитация у большинства протекает параллельно с десоциализацией, при которой вследствие воздействия внешних факторов стираются привычные ранее для индивида социальные ценности, установки, нормы. В результате чего возможно отдаление от своих социальных групп или общества в целом. Причин тому может быть несколько.

Во-первых, ввиду нахождения в условиях вынужденной социальной изоляции. Самым сложным на пути адаптации к новой жизненной ситуации может стать состояние одиночества. Его причины и характер могут быть различными. В социологическом исследовании, направленном на изучение феномена старости, В.Н. Иванов выделил два типа одиночества: добровольное и вынужденное. Последнее из которых является, на его взгляд, противоестественным состоянием. «Поскольку человек существо социальное, ему необходимо находиться в регулярных социальных взаимодействиях с себе подобными» [10, с. 166].

Во-вторых, наблюдается несоответствие в большинстве стационарных учреждений социального обслуживания граждан пожилого возраста условий проживания современному уровню комфорта. На сегодняшний день большинство из них представляют собой приюты казарменного типа. Что противоречит поручениям заместителя председателя правительства Российской Федерации О.Ю. Голодец в адрес Министерства труда и социальной защиты РФ и Министерства строительства и жилищно-коммунального хозяйства РФ о создании типовых проектов малокомплектных геронтологических центров, рассчитанных не более чем на 150 человек [17].

Геронтологический центр представляет собой «учреждение медико-социального профиля для граждан старших возрастных групп, которое помогает продлить им активность и сохранить высокий уровень жизни» [4]. В его состав входят гериатрическая поликлиника, гериатрический стационар и бюро социальной помощи. Геронтологические центры являются на сегодняшний день инновационной технологией по уходу за пожилыми людьми. Однако их количество в регионах продолжает быть незначительным. По данным федерального государственного статистического наблюдения, по состоянию на 1 января 2016 г. в Российской Федерации функционировало более 1354 стационарных учреждений социального обслуживания для граждан пожилого возраста и инвалидов. В числе этих учреждений более 756 домов-интернатов общего типа, свыше 540 психоневрологических домов-интернатов, 21 дом милосердия, 28 геронтологических центров, 222 специальных дома для одиноких престарелых [7]. Таким образом, очевидна необходимость внедрения современных форм и технологий работы в деятельность учреждений социально-реабилитационного обслуживания пожилых людей. В России существуют коммерческие геронтологические центры, но количество их незначительное (только в крупных мегаполисах), что объясняется низким уровнем платежеспособности пенсионеров. Непосильная ноша в организации жизнедеятельности социально одиноких пожилых людей целиком и полностью возложена на государство.

Типы домов для проживания и время препровождения людей «третьего возраста». Следует отметить, что в странах Европы и Америки львиная доля подобного рода учреждений является частными с незначительным государственным финансированием. Основные расходы принадлежат страховым компаниям или покрываются за счет личных средств клиентов. Этим и объясняется соответствующий уровень и спектр предос- 
тавляемых услуг. В подтверждение этому обратимся к классификации существующих в Великобритании домов для проживания и времяпрепровождения людей «третьего возраста»: собственные дома, жилье для пенсионеров, дома с уходом, дома престарелых, пансионаты для людей с деменцией, учреждения с полным спектром социальных и медицинских услуг [25]. В США помимо вышеупомянутых форм проживания функционируют сообщества для людей в возрасте, поселения пенсионеров, а также учреждения для совместного проживания пенсионеров [26]. Развернутый анализ учреждений для проживания людей пожилого возраста за рубежом был представлен в исследовании А.И. Андросова, А.В. Копьева, О.В. Масловской, направленном на выявление особенностей проектирования подобного рода учреждений в отечественной и зарубежной практике [1, с. 13].

Проведенный нами контент-анализ сайтов зарубежных коммерческих учреждений для проживания и времяпрепровождения людей «третьего возраста» позволил систематизировать данные по типам учреждений:

1. «Независимое проживание» (Independent Living) - представляет собой жилые комплексы для пенсионеров в виде многоквартирных домов или коттеджей с общей территорией, неподалеку от которых расположены медицинские учреждения, торгово-развлекательные центры, спортивные комплексы, рестораны и иные сети общественного питания. Здесь проводятся развлекательные мероприятия, организуются тренинги и обучающие мастер-классы, экскурсии. Кроме того, условия проживания рассчитаны на индивидуальные физические особенности. Например, расширены дверные проемы, здания оборудованы специальными лифтами и санузлами, мебель приспособлена для максимально комфортного уровня жизнедеятельности для лиц преклонного возраста, имеющих ограниченные возможности здоровья. В стоимость проживания может быть включено трехразовое питание, помощь с покупками и иные виды социальных услуг. Данный вид домов престарелых считается наиболее доступным.

2. «Проживание с предоставлением частичного ухода» (Assisted Living) - включает в себя помимо вышеперечисленных услуг круглосуточный присмотр и оказание бытовых и частично медицинских услуг.

3. «Дом престарелых с медицинским обслуживанием» (Nursing Home) - предлагает весь спектр социальных услуг и круглосуточное сопровождение медицинским персоналом.

4. «Долгосрочный уход» (Long Term Care) - в нем проживают лица, находившиеся ранее в других вышеперечисленных типах жилья для лиц преклонного возраста, но утратившие способность к самообслуживанию.

Таким образом, анализ зарубежных источников позволяет вычленить четыре основных типа учреждений для пожилых людей:

- неспециализированные комплексы с независимым проживанием, адаптированные для пожилых людей;

- комплексы для проживания с персональным уходом;

- специализированные комплексы с персональным уходом и медицинскими услугами;

- специализированные комплексы с полным спектром социальных, медицинских и иных услуг. Например, дома для лиц преклонного возраста, разрешающие или запрещающие проживание с животными, дома для пожилых людей с нетрадиционной ориентацией, с определенными религиозными и политическими убеждениями и др.

Задачи интегрированных учреждений совместного проживания. В рамках нашего исследования особого внимания заслуживают учреждения для совместного проживания пожилых людей и выпускников детских домов, поскольку создание интегрированных учреждений позволило бы решить ряд общественно значимых задач для социальной политики государства.

Во-первых, позволит преодолеть социальную изоляцию пожилых людей. В стационарных учреждениях социального обслуживания граждан большинство находится вынужденно в связи с физическим угасанием, утратой возможности к самообслуживанию, социальным одиночеством и иными неблагоприятными обстоятельствами. Поскольку основным условием полноценной жизни является активное взаимодействие с окружающими, новый подход в организации совместной жизнедеятельности лиц «третьего возраста» и выпускников детских домов позволит не толь- 
ко повысить интерес лиц преклонного возраста к совместному времяпровождению, но и приведет к возможному спаду уровня «социального отчуждения личности» $[11$, с. 35$]$. Для устранения отчуждения личности у пожилых людей необходим регулярный организованный процесс вовлечения их в социально-культурную деятельность. В связи с этим разрабатываются различные программы и проекты, способствующие интеграции людей «третьего возраста» в социокультурное пространство. Особого внимания заслуживает деятельность благотворительного фонда «Старость в радость», направленная на психологическую, медицинскую, материальную помощь и поддержку пожилых людей со стороны добровольцев. Для того чтобы компенсировать недостаток общения у граждан пожилого возраста, проживающих в социальных учреждениях, был разработан инновационный проект «Внуки по переписке» [2, с. 15]. Следует отметить, что организация социокультурной деятельности пожилых людей в нашей стране осуществляется лишь на уровне пилотных проектов и требует более детальной разработки. Иным образом обстоит дело за рубежом. Например, в Словении для пенсионеров распространен такой вид некоммерческих услуг, как «бебиситтерство» (присмотр за чужими детьми). Забота о ребенке за довольно низкую заработную плату воспринимается ими как помощь ближнему в роли «суррогатной бабушки» или «суррогатного дедушки» [22, с. 168]. По аналогии с данной моделью в Белгородской области были организованы «волонтерские движения с привлечением в его ряды пожилых людей», стремящихся оказывать помощь обществу [24, с. 118].

Во-вторых, улучшит контроль за деятельностью стационарных учреждений социального обслуживания для граждан пожилого возраста. В настоящее время проблема повышения качества жизни пожилых людей и снижения их социальной напряженности является актуальной темой научных исследований. Одним из действенных способов ее решения выступает реорганизация стационарных учреждений для граждан пожилого возраста, а также внедрение новых форм и методов работы с пожилыми людьми [15, с. 30]. Материалы геронтологических исследований пос- ледних лет свидетельствуют о том, что с возрастом меняется иерархия ценностей, на первом плане у людей пожилого возраста появляется повышенный интерес к духовному и физическому состоянию и развитию, жизнь наполняется желанием бесконечности. Однако планомерное протекание данных психофизиологических процессов возможно лишь в благоприятных условиях. Жизнь в социально-реабилитационных учреждениях для граждан пожилого возраста звучит для большинства жителей нашей страны как приговор. Однако увеличивающийся показатель продолжительности жизни на фоне процесса технологизации и повышающихся требований к уровню комфорта требует кардинальных перемен.

В-третьих, позволит оптимизировать социализацию воспитанников детских домов. Безусловно, социальное сиротство накладывает отпечаток на духовное и физическое развитие личности, становится причиной низкого уровня социальной активности, некомпетентности в решении экономических, политических, жилищно-бытовых вопросов и, как следствие, вызывает отклонение их социального и личностного развития. Согласно данным проведенных исследований в результате длительного пребывания в условиях сиротского учреждения формируется особый тип личности. Как правило, это «пассивный потребитель», у которого отсутствует стремление к достижению поставленных целей, умение самостоятельно принимать решения, потребность в какой-либо деятельности [13, с. 77]. В большинстве своем воспитанники детских домов чувствуют себя выброшенными за пределы общественных связей, несмотря на существующие меры социальной поддержки со стороны государства. Прежде всего им необходимы регулярное дружеское общение, наставления, психологическая поддержка и внимание со стороны взрослых людей. Всего этого можно достичь при условии совместного проживания выпускников детских домов с людьми пожилого возраста в специально оснащенных социально-реабилитационных центрах. Вместе они образуют группу взаимопомощи, способную искоренить проблемы социального отчуждения и социальной изоляции.

В-четвертых, это позволит сократить расходы на социальную поддержку детей-си- 
рот и детей, оставшихся без попечения родителей, за счет работы с ними пожилых людей в качестве волонтеров и их совместного проживания до момента предоставления жилья детям-сиротам. Согласно Федеральному закону от 21 декабря 1996 г. № 159-ФЗ «О дополнительных гарантиях по социальной поддержке детей-сирот и детей, оставшихся без попечения родителей» и иным федеральным и региональным нормативно-правовым актам основной мерой государственной поддержки является обеспечение выпускников детских домов жильем [18]. По данным Министерства образования и науки РФ численность детейсирот и детей, оставшихся без попечения родителей, состоящих на учете на получение жилого помещения, по состоянию на 1 октября 2015 г. составила 206301 человек. Из них численность детей-сирот и детей, оставшихся без попечения родителей, в возрасте от 14 до 18 лет - 77003 человека, лиц из числа детей-сирот и детей, оставшихся без попечения родителей, в возрасте от 18 лет и старше 128998 человек. Стоит отметить, что проводится регулярный мониторинг исполнения комплекса мер по предоставлению жилья детямсиротам и детям, оставшимся без попечения родителей, утвержденный распоряжением Правительства Российской Федерации от 22 января 2015 года. Анализ его данных показал, что в 2016 г. жилыми помещениями было обеспечено 25,3 тысячи детей-сирот и лиц из их числа. Однако по сравнению с 2015 г. данный показатель уменьшился на 1,3 тысячи человек [16].

Выводы. Таким образом, в рамках имеющихся возможностей и ресурсов перед российским государством стоит достаточно сложная задача - ресоциализация граждан пожилого возраста, находящихся в условиях стационарных учреждений социального обслуживания, посредством их участия в социализации воспитанников детских домов. Как писал Г. Гессе, старость - это «ступень жизни, имеющая, как и все другие ее ступени, свое собственное лицо, собственную атмосферу и температуру, собственные радости и горести. У седовласых стариков, как и у их младших собратьев, должна быть своя задача, придающая смысл их существованию» [23, с. 119]. Неидентичные практики, различия в социокультурных условиях порождают трудности ресоциализации людей пожилого возраста. Системообразующим в данном процессе является межпоколенческое взаимодействие. Отметим, что проведенный анализ зарубежного опыта технологии включения пожилых людей в общественную жизнь позволяет нам сделать вывод о неоценимом вкладе людей «третьего возраста» в процесс социализации молодежи и определить перспективы использования зарубежного опыта в РФ посредством трансформации геронтологических институтов.

\section{СПИСОК ЛИТЕРАТУРЫ}

1. Андросов, А. И. Анализ отечественного и зарубежного опыта проектирования жилья для людей пожилого возраста / А. И. Андросов, А. В. Копьева, О. В. Масловская // Новые идеи нового века : материалы Междунар. науч. конф. ФАД ТОГУ. Хабаровск : Тихоокеан. гос. ун-т, 2017. - Т. 2. С. $12-16$.

2. Бакулина, А. С. Социальное служение в России: вопросы теории и практики (на примере благотворительного фонда «Старость в радость») / А. С. Бакулина // Актуальные проблемы науки, образования и социальной работы : сб. науч. ст. / РГСУ филиал в г. Люберцы ; Ин-т психологии, социологии и соц. отношений ГАОУ ВО МГПУ. М. : Перо, 2015. - С. 11-20.

3. Боулби, Д. Создание и разрушение эмоциональных связей / Д. Боулби. - М. : Акад. проект, 2004. -232 c.

4. Выписка из протокола заседания Совета при Правительстве Российской Федерации по вопросам попечительства в социальной сфере от 29 ноября 2016 г. - Электрон. текстовые дан. - Режим доступа: http:/government.ru/info/25638/ (дата обращения: 15.02.2018). - Загл. с экрана.

5. Гилинский, Я. И. Девиантология: социология преступности, наркотизма, проституции, самоубийств и других отклонений / Я. И. Гилинский. СПб. : Юрид. центр «Пресс», 2004. - 520 с.

6. Деркач, А. А. Развитие в акмеологии и акмеологическое развитие в структуре онтогенеза / А. А. Деркач, Э. В. Сайко // Мир психологии. 2007. - № 2. - С. 43-55.

7. Доклад о результатах и основных направлениях деятельности Министерства труда и социальной защиты Российской Федерации на 20152017 годы. - Электрон. текстовые дан. - Режим доступа: https://rosmintrud.ru/ministry/about/reports/2 (дата обращения: 15.02.2018). - Загл. с экрана. 
8. Ермолаева, М. В. Проблема социализации и развития личности в старости / М. В. Ермолаева // Современная социальная психология: теоретические подходы и прикладные исследования. - 2012. № 2 (15). - С. 96-102.

9. Змановская, Е. В. Теоретико-методологическое обоснование общей теории девиантности и девиантного поведения / Е. В. Змановская // Ученые записки Санкт-Петербургского государственного института психологии и социальной работы. 2008. - Т. 9, вып. 1. - С. 133-138.

10. Иванов, В. Н. Феномен старости / В. Н. Иванов // Социологические исследования. - 2017. № 11.-C. 164-170.-DOI: 10.7868/S0132162517110186.

11. Исупова, О. Г. Гендер и старость: теоретические подходы / О. Г. Исупова // Демоскоп Weekly. - 2010. - № 433-434. - Электрон. текстовые дан. - Режим доступа: http://www.demoscope.ru/ weekly/2010/0433/analit05.php (дата обращения: 18.02.2018). - Загл. с экрана.

12. Клейберг, Ю. А. Социальная неопределенность личности как фактор девиантного поведения. Психология / Ю. А. Клейберг // Историко-критические обзоры и современные исследования. 2015. - № 4-5. - С. 8-17.

13. Краснова, В. Г. Персонализация жизненного пространства как условие реабилитации детей, оставшихся без попечения родителей / В. Г. Краснова // Социальная работа и социальная педагогика в России и Германии: ведущие тенденции и динамика их развития : материалы Междунар. науч.-практ. конф. 25-26 окт. 2007 г. - Астрахань : Изд. дом «Астрахан. ун-т», 2007. - С. 78-80.

14. Кудрявцев, В. Н. Социальные деформации (причины, механизмы и пути преодоления) / В. Н. Кудрявцев. - М. : Ин-т гос-ва и права РАН, 1992. - 133 с.

15. Моздокова, Ю. С. Пути повышения социально-культурного статуса лиц пожилого возраста / Ю. С. Моздокова, Ю. Д. Красильников, Т. Г. Киселева // Социально-культурная деятельность: поиски, проблемы, перспективы. - М. : Москов. гос. ун-т культуры и искусства, 2000. - С. 28-35. - Электрон. текстовые дан. - Режим доступа: http://elibrary.ru/ item.asp?id=24396538 (дата обращения: 17.02.2018). Загл. с экрана.

16. Об утверждении комплекса мер по предоставлению жилья детям-сиротам, детям, оставшимся без попечения родителей, и лицам из их числа на 2015-2017 годы // Портал Правительства России. Электрон. текстовые дан. - Режим доступа: http:// government.ru/docs/16643/ (дата обращения: 16.02.2018). - Загл. с экрана.

17. Постановление Министерства труда и социального развития Российской Федерации от 25 декабря 2003 г. № 90 «Об утверждении методических рекомендаций по организации диетическо- го (лечебного) питания в государственных (муниципальных) учреждениях социального обслуживания граждан пожилого возраста и инвалидов». Электрон. текстовые дан. - Режим доступа: http:// www.alppp.ru/law/hozjajstvennaja-dejatelnost/ obschestvennoe-pitanie/2/postanovlenie-mintruda-rfot-25-12-2003-90.html. - Загл. с экрана.

18. Российская Федерация. Федеральный закон от 21 декабря 1996 г. № 159-Ф3 «О дополнительных гарантиях по социальной поддержке детей-сирот и детей, оставшихся без попечения родителей». - Доступ из справ.-правовой системы «КонсультантПлюс».

19. Сапожникова, Т. И. Социально-культурная деятельность пожилых людей как способ интеграции и адаптации в современном обществе / Т. И. Сапожникова // Вестник ЧитГУ. - 2012. - № 5 (84). - С. 103-107.

20. Сукало, А. А. Самодеятельное творчество в современных условиях: проблемы и перспективы / А. А. Сукало // Вестник Санкт-Петербургского государственного университета культуры и искусств. - 2011. - № 2. - С. 70-78. - Электрон. текстовые дан. - Режим доступа: http://elibrary.ru/item. asp?id=16589293 (дата обращения: 04.02.2018). - Загл. с экрана.

21. Харьковская, Е. В. Социокультурная деятельность с людьми третьего возраста по преодолению социального отчуждения: региональный аспект / Е. В. Харьковская, Е. В. Мирошниченко, Г. Н. Тутаева // Интеграция образования. - 2016. Т. 20, № 2 (83). - С. 188-197.

22. Хумер, Ж. Государственная забота о детях в Словении и ее влияние на неформальные рынки домашних услуг / Ж. Хумер, М. Хрженяк //Laboratorium. Журнал социальных исследований. - 2016. - № 3. C. 164-169.

23. Шутценбергер, А. А. Синдром предков / А. А. Шутценбергер. - М. : Изд-во Ин-та психотерапии, 2001.-210 с.

24. Ярошенко, Н. Н. Социально-культурная деятельность: Парадигмы, методология, теория : монография / Н. Н. Ярошенко. - М. : МГУКИ, 2000. $204 \mathrm{c}$.

25. Age United Kingdom. - Electronic text data. Mode of access: http://www.ageuk.org.uk/ (date of access: 16.02.2018). - Title from screen.

26. Ginzler Elinor. Which Type of Housing Is Best for You? AARP. July 2009. - Electronic text data. - Mode of access: https://www.aarp.org/home-garden/ housing/info-08-2009/ginzler_housing_choices.html (date of access: 16.02.2018). - Title from screen.

\section{REFERENCES}

1. Androsov A.I., Kopyeva A.V., Maslovskaya O.V. Analiz otechestvennogo i 
zarubezhnogo opyta proektirovaniya zhilya dlya lyudey pozhilogo vozrasta [Analysis of domestic and foreign experience in designing housing for the elderly]. Novye idei novogo veka : materialy Mezhdunar. nauch. konf. FAD TOGU. Khabarovsk, Tikhookean. gos. un-t, 2017, vol. 2, pp. 12-16.

2. Bakulina A.S. Sotsialnoe sluzhenie v Rossii: voprosy teorii i praktiki (na primere blagotvoritelnogo fonda «Starost v radost») [Social Service in Russia: Issues of Theory and Practice (on the Example of the Charitable Foundation Old Age for Joy]. Aktualnye problemy nauki, obrazovaniya i sotsialnoy raboty: sb. nauch. st. Moscow, Pero Publ., 2015, pp. 11-20.

3. Boulbi D. Sozdanie $i$ razrushenie emotsionalnykh svyazey [Creation and destruction of emotional bonds]. Moscow, Akad. proekt Publ., 2004. 232 p.

4. Vypiska iz protokola zasedaniya Soveta pri Pravitelstve Rossiyskoy Federatsii po voprosam popechitelstva $v$ sotsialnoy sfere ot 29 noyabrya $2016 \mathrm{~g}$. [Extract from the minutes of the meeting of the Council of the Government of the Russian Federation on the issues of guardianship in the social sphere of November 29, 2016]. URL: http://government.ru/info/ 25638/. (accessed 15 February 2018).

5. Gilinskiy Ya.I. Deviantologiya: sotsiologiya prestupnosti, narkotizma, prostitutsii, samoubiystv $i$ drugikh otkloneniy [Deviantology: The Sociology of Crime, Narcotism, Prostitution, Suicide and Other Deviations]. Saint Petersburg, Press, 2004. 520 p.

6. Derkach A.A., Sayko E.V. Razvitie v akmeologii i akmeologicheskoe razvitie v strukture ontogeneza [Development in acmeology and acmeological development in the structure of ontogeny]. Mir psikhologii, 2007, no. 2, pp. 43-55.

7. Doklad o rezultatakh $i$ osnovnykh napravleniyakh deyatelnosti Ministerstva truda $i$ sotsialnoy zashchity Rossiyskoy Federatsii na 2015 2017 gody [Report on the results and main activities of the Ministry of Labor and Social Protection of the Russian Federation for 2015-2017]. URL: https:// rosmintrud.ru/ministry/about/reports/2. (accessed 15 February 2018).

8. Ermolaeva M.V. Problema sotsializatsii i razvitiya lichnosti $\mathrm{v}$ starosti [The problem of socialization and development of the individual in old age]. Sovremennaya sotsialnaya psikhologiya: teoreticheskie podkhody i prikladnye issledovaniya, 2012, no. 2 (15), pp. 96-102.

9. Zmanovskaya E.V. Teoretiko-metodologicheskoe obosnovanie obshchey teorii deviantnosti i deviantnogo povedeniya [Theoretical and methodological justification of the general theory of deviance and deviant behavior]. Uchenye zapiski Sankt-Peterburgskogo gosudarstvennogo instituta psikhologii i sotsialnoy raboty, 2008, vol. 9, iss. 1, pp. 133-138.
10. Ivanov V.N. Fenomen starosti [The phenomenon of old age]. Sotsiologicheskie issledovaniya, 2017, no. 11, pp. 164-170. DOI: 10.7868/ S0132162517110186.

11. Isupova O.G. Gender i starost: teoreticheskie podkhody [Gender and Old Age: Theoretical Approaches]. Demoskop Weekly, 2010, no. 433-434. URL: http:/www.demoscope.ru/weekly/2010/0433/ analit05.php (accessed 18 February 2018).

12. Kleyberg Yu.A. Sotsialnaya neopredelennost lichnosti kak faktor deviantnogo povedeniya. Psikhologiya [The social uncertainty of the individual as a factor of deviant behavior. Psychology]. Istorikokriticheskie obzory i sovremennye issledovaniya, 2015, no. 4-5, pp. 8-17.

13. Krasnova V.G. Personalizatsiya zhiznennogo prostranstva kak uslovie reabilitatsii detey, ostavshikhsya bez popecheniya roditeley [Personalization of the living space as a condition for the rehabilitation of children left without parental care]. Sotsialnaya rabota $i$ sotsialnaya pedagogika $v$ Rossii $i$ Germanii: vedushchie tendentsii $i$ dinamika ikh razvitiya: materialy Mezhdunar. nauch.-prakt. konf. 25-26 okt. 2007 g. Astrakhan, AGU Publ., 2007, pp. $78-80$.

14. Kudryavtsev V.N. Sotsialnye deformatsii (prichiny, mekhanizmy i puti preodoleniya) [Social deformations (Causes, mechanisms and ways to overcome)]. Moscow, In-t gos-va i prava RAN, 1992. $133 \mathrm{p}$.

15. Mozdokova Yu.S., Krasilnikov Yu.D., Kiseleva T.G. Puti povysheniya sotsialno-kulturnogo statusa lits pozhilogo vozrasta [Ways to improve the socio-cultural status of the elderly]. Sotsialnokulturnaya deyatelnost: poiski, problemy, perspektivy. Moscow, Moskov. gos. un-t kultury i iskusstva, 2000, pp. 28-35. URL: http://elibrary.ru/ item.asp? $\mathrm{id}=24396538$ (accessed 17 February 2018).

16. Ob utverzhdenii kompleksa mer po predostavleniyu zhilya detyam-sirotam, detyam, ostavshimsya bez popecheniya roditeley, i litsam iz ikh chisla na 2015-2017 gody: portal Pravitelstva Rossii [On approval of a set of measures for the provision of housing to orphans, children left without parental care for 2015-2017: the portal of the Government of Russia]. URL: http://government.ru/ docs/16643/. (accessed 16 February 2018).

17. Postanovlenie Ministerstva truda $i$ sotsialnogo razvitiya Rossiyskoy Federatsii ot 25 dekabrya $2003 \mathrm{~g}$. № 90 «Ob utverzhdenii metodicheskikh rekomendatsiy po organizatsii dieticheskogo (lechebnogo) pitaniya $v$ gosudarstvennykh (munitsipalnykh) uchrezhdeniyakh sotsialnogo obsluzhivaniya grazhdan pozhilogo vozrasta i invalidov» [Decree of the Ministry of Labor and Social Development of the Russian Federation of 
December 25, 2003 No. 90 ‘On Approval of Guidelines for the Organization of Dietary (Medical) Nutrition in State (Municipal) Institutions of Social Services for the Elderly and the Disabled']. URL: http:// www.alppp.ru/law/hozjajstvennaja-dejatelnost/ obschestvennoe-pitanie/2/postanovlenie-mintruda-rfot-25-12-2003-90.html.

18. Rossiyskaya Federatsiya. Federalnyy zakon ot 21 dekabrya 1996 g. № 159-FZ «O dopolnitelnykh garantiyakh po sotsialnoy podderzhke detey-sirot $i$ detey, ostavshikhsya bez popecheniya rodite ley» [Russian Federation. Federal Law of December 21, 1996 No. 159-FZ 'On Additional Guarantees for Social Support of Orphans and Children Left Without Care of Parents']. Access from Reference Legal system 'KonsultantPlyus'.

19. Sapozhnikova T.I. Sotsialno-kulturnaya deyatelnost pozhilykh lyudey kak sposob integratsii i adaptatsii v sovremennom obshchestve [Socio-cultural activities of older people as a way of integration and adaptation in modern society]. Vestnik CHitGU, 2012, no. 5 (84), pp. 103-107.

20. Sukalo A.A. Samodeyatelnoe tvorchestvo v sovremennykh usloviyakh: problemy i perspektivy [Amateurish creation in the present conditions: problems and prospects]. Vestnik Sankt-Peterburgskogo gosudarstvennogo universiteta kultury i iskusstv, 2011, no. 2, pp. 70-78. URL: http://elibrary.ru/item. asp?id=16589293 (accessed 4 February 2018).
21. Kharkovskaya E.V., Miroshnichenko E.V., Tutaeva G.N. Sotsiokulturnaya deyatelnost $\mathrm{s}$ lyudmi tretyego vozrasta po preodoleniyu sotsialnogo otchuzhdeniya: regionalnyy aspekt [Sociocultural activities with people of the third age to overcome social exclusion: the regional aspect]. Integratsiya obrazovaniya, 2016, vol. 20, no. 2 (83), pp. 188-197.

22. Khumer Zh., Khrzhenyak M. Gosudarstvennaya zabota o detyakh v Slovenii i ee vliyanie na neformalnye rynki domashnikh uslug [State care for children in Slovenia and its impact on informal markets for domestic services]. Laboratorium. Zhurnal sotsialnykh issledovaniy, 2016, no. 3, pp. 164-169.

23. Shuttsenberger A.A. Sindrom predkov [Syndrome of ancestors]. Moscow, Izd-vo In-ta psikhoterapii, 2001. $210 \mathrm{p}$.

24. Yaroshenko N.N. Sotsialno-kulturnaya deyatelnost: Paradigmy, metodologiya, teoriya: monografiya [Socio-cultural activities: Paradigms, methodology, theory. Monograph]. Moscow, MGUKI Publ., 2000. 204 p.

25. Age United Kingdom. URL: http:// www.ageuk.org.uk/ (accessed 16 February 2018).

26. Ginzler E. Which Type of Housing Is Best for You? AARP, July 2009. URL: https://www.aarp.org/ home-garden/housing/info-08-2009/ginzler_housing_ choices.html (accessed 16 February 2018).

\section{Information about the Author}

Elena A. Kuzmina, Postgraduate Student, Assistant of Department of Social Work and Pedagogy, Volgograd State University, Prosp. Universitetsky, 100, 400062 Volgograd, Russian Federation, srm@volsu.ru.

\section{Информация об авторе}

Елена Алексеевна Кузьмина, аспирант, ассистент кафедры социальной работы и педагогики, Волгоградский государственный университет, просп. Университетский, 100, 400062 г. Волгоград, Российская Федерация, srm@volsu.ru. 